\title{
Sinergitas Program Matoanisasi pada Masyarakat Desa Gunting Melalui Participatory Rural Appraisal (PRA)
}

\author{
Aslikhah \\ Universitas Yudharta Pasuruan \\ Email: aslikhah@yudharta.ac.id
}

\begin{abstract}
:
To Sukorejo The City of Matoa, Sukorejo subdistrict always distributes Matoa tree seedlings from year to year, which is spread in 19 villages, one of which is the Scissors village which is the first ring in spreading Matoa tree seedlings. However, Gunting villagers still do not know more about the types or benefits of these Matoa trees and fruits. This program takes the theme of entrepreneurship which will be implemented in Gunting village of Sukorejo Sub-district of Pasuruan Regency using the Participatory Rural Appraisal (PRA) method. The purpose of this program is to increase the understanding of Gunting village community on the use of Matoa trees and fruits so that they have high economic value. The results of this program are the community ranging from adults to children more familiar with Matoa fruit and Matoa trees, as well as variants of products from processed Matoa fruit. In addition to these results, this assistance also resulted in an attractive way of packaging products, as well as an understanding of the procedures for obtaining products that have SNI standards.
\end{abstract}

Keyword: Matoa, Participatory Rural Appraisal.

\section{Pendahuluan}

Desa Gunting merupakan salah satu desa dalam wilayah kecamatan Sukorejo kabupaten Pasuruan dengan luas wilayah sekitar 530 hektar. Jumlah penduduk pada akhir tahun 2017 sejumlah 5157 jiwa dengan tingkat kepadatan penduduk sudah mencapai 5.000 lebih jiwa, memiliki jarak orbitasi dengan kecamatan sekitar $3 \mathrm{~km}, 35 \mathrm{~km}$ dari wilayah ibu kota kabupaten dan $70 \mathrm{~km}$ dari wilayah ibu kota provinsi dengan fasilitas jalan propinsi dan jalan kabupaten yang cukup memadahi.Secara administratif desa Gunting terdiri dari 03 dusun, 15 Rukun Warga (RW) dan 31 Rukun Tetangga (RT). 
62 | Sinergitas Program Matoasisasi pada Masyarakat Desa Gunting...

Desa Gunting memiliki letak yang strategis berada dijalur kawasan wisata sukorejo tretes. Keadaan alam secara umum merupakan lahan pertanian persawahan (sekitar 145 hektar) dan tegalan (sekitar 279 hektar) dan hanya sebagian kecil kawasan industri, sebagian besar lahan pertanian beririgasi teknis sehingga desa Gunting merupakan kawasan yang memiliki produktifitas/hasil pertanian yang cukup tinggi, disamping itu letaknya yang berbatasan denga kecamatan prigen, yang merupakan desa wisata, disamping pertanian yang menjadi andalan sebagian masyarakat utamanya generasi muda banyak bergerak disektor industri (menjadi pekerja swasta) sehingga secara umum kondisi perekonomian masyarakat berada pada kategori cukup.

Menuju Sukorejo The City of Matoa, kecamatan Sukorejo senantiasa melakukan pendistribusian bibit pohon Matoa. Jika tahun 2018 ada sekitar 5.500 bibit yang telah didistribusikan, maka tahun ini mencapai 5.800 bibit. Seluruhnya tersebar di 19 desa di wilayah kecamatan Sukorejo, dan desa Guntung merupakan area ring satu dalam pembibitan buah matoa.

Menurut Camat Sukorejo, Diano Vela Very Santoso meyakini bahwa buah Matoa yang banyak tumbuh di Papua dan memiliki nama latin Donetia Pinnata/ Pometia Pinnata tersebut akan memberikan manfaat untuk masyarakat sekitanya. Ide munculnya budidaya buah matoa dikembangkan di Sukorejo sejak tahun 2014 lalu. Hasilnya, selain rasa buah yang sangat enak dan legit, cara perawatannya juga tidak sulit karena tidak membutuhkan kondisi tanah tertentu.

Dijelaskan Diano, "Matoa memiliki bentuk buah yang melonjong seperti buah Pinang atau telur puyuh. Apabila muda berwarna hijau kekuningan dan ketika buah matoa sudah masak akan berubah warna menjadi cokelat kehitaman. Disamping itu, kulit arinya putih bening melekat pada biji, manis dan harum. Selain rasa manis pada buahnya, Matoa juga mempunyai manfaat bernilai ekonomi mulai dari kayu, buah bahkan daunnya. Kayu pohon Matoa sangat kuat dan bagus untuk dijadikan tiang bangunan, lantai, kusen, perahu dan kerajinan atau mebel karena setara dengan kayu Eboni dan Jati. Buah Matoa kebetulan tidak mengenal 
musim, jadi panennya bisa terus menerus. Kalau sudah jadi Wisata Petik Matoa, maka tentunya akan memiliki kontribusi tersendiri untuk pemkab Pasuruan.”

Pemberdayaan ekonomi lokal melalui penanaman pohon matoa terus dilakukan oleh Pemerintah Kecamatan Sukorejo. Hal ini dilakukan menyusul pohon matoa tumbuh subur dan berbuah di desa - desa di Kecamatan Sukorejo. Bahkan, beberapa waktu lalu, sejumlah warga dan ibu - ibu telah mendapatkan pelatihan khusus pengolahan buah matoa di PPK Sampoerna menjadi Sirup, dodol, manisan maupun sari buah."Kami akan menjadikan Kecamatan Sukorejo sebagai sentra kluster perkebunan pohon matoa. Insyaallah akan membantu pengembangan ekonomi lokal masyarakat, " tegas Diano.Target utama dari program Sukorejo City of Matoa adalah penanaman 10.000 pohon matoa di 5 Desa yaitu Desa Ngadimulyo, Desa Suwayuwo, Desa Gunting, Desa Lemahbang, dan Desa Pakukerto. Sampai nanti 19 Desa bisa terwujud tertanam 2.000 - 3.000 pohon dengan support CSR Sampoerna, APBD dan APBDes serta bantuan lain yang sah dan tidak mengikat.

Ditargetkan, 4 tahun mendatang yaitu tahun 2018, Sukorejo akan berubah wajah menjadi "City of Matoa". Bahkan, Diano optimis bahwa Sukorejo akan memiliki Wisata Petik Matoa."Buah Matoa kebetulan juga tidak mengenal musim, jadi panennya bisa terus menerus. Kalau sudah jadi wisata petik matoa, maka tentu akan memberikan kontribusi tersendiri untuk Pemkab Pasuruan," jelasnya.

Setelah Program Penanaman Pohon Matoa (Pometia Pinnata) yang ditandai dengan penanaman 5.500 pohon matoa di 19 Desa se-Kecamatan Sukorejo diluncurkan Camat Diano Vela Fery Santoso, beberapa waktu lalu, kemudian telah digelar juga pelatihan pembibitan dan penanaman matoa pada tanggal 7-8 Oktober 2015 di Desa Gunting.

Pelatihan ini menghadirkan 2 narasumber yang berkompeten di bidangnya dan dihadiri oleh 50 orang perwakilan dari 5 Desa. Pada hari pertama, peserta diberi pengetahuan tentang pembibitan pohon matoa dimana perbanyakan matoa secara umum bisa dilakukan melalui 2 cara yaitu secara generatif / biji dan 
64 | Sinergitas Program Matoasisasi pada Masyarakat Desa Gunting...

vegetatif. Pada hari kedua, peserta diberikan pembelajaran tentang teknis budidaya pohon matoa. Prosesnya dimulai dari pembuatan pupuk, cara penanaman, cara perawatan hingga cara mengatasi hama penyakit yang biasa menyerang pohon matoa. Untuk mengatasi hama dan penyakit pohon matoa khususnya menjelang panen, diberikan informasi bagaimana mengatasi hama penggerek batang dan khususnya adalah hama kelelawar pemakan buah.

Selain itu Pemerintah Kecamatan juga telah menggelar Pelatihan Olahan Pangan Buah Matoa, pada hari ini, Kamis 29 Oktober 2015 di PPK Sampoerna. Pelatihan ini menghadirkan tutor dri Yayasan Kaliandra dan diikuti sekitar 50 ibuibu sebagai pioner mengoptimalkan gerakan matoanisasi. Dalam Pelatihan Olahan Pangan Buah Matoa, para peserta mendapatkan teori, yang kemudian langsung dipraktekkan. Dan olahanya berupa selai, dodol, sirup, sari buah, manisan basah kering. Pelatihan ini merupakan rangkaian program mewujudkan Sukorejo City of Matoa yang digagas Pemerintah Kecamatan Sukorejo, Diano Vela Fery S, S.Sos., M.A..

Masyarakat Desa Gunting masih belum mengenal dengan baik tentang pohon dan buah Matoa, hal ini disebabkan karena pohon Matoa merupakan pohon yang berasal dari Papua yang bernama latin (Pometia Pinnata), dan buah Matoa tidak sepopuler seperti buah durian, Mangga, Kelengkeng dll. Dengan melihat kondisi seperti yang telah dipaparkan diatas, tim pendampingan tertarik untuk melakukan kegiatan pendampingan di desa Sukorejo dengan mengambil tema sinergitas program Matoanisasi pada masyarakat desa Gunting melalui Participatory Rural Appraisal (PRA).

Tujuan dari kegiatan pendampingan ini diharapkan masyarakat desa Gunting bisa mengenal lebih baik akan manfaat dan nilai tambah dari pohon dan buah matoa, tidak hanya mengenal tetapi bisa mengelolah hasil dari buah Matoa menjadi hasil olahan produk yang bisa memiliki nilai ekonomi yang tinggi bagi masyarakat desa Gunting sehingga ekonomi masyarakat desa Gunting bisa menjadi 
lebih baik dengan adanya sinergi program Matoanisasi yang diselenggarakan pemerintah kecamatan Sukorejo terhadap masyarakat desa Gunting.

\section{Metode}

Pelaksanaan program ini dilaksanakan dengan pendekatan pemberdayaan masyarakat dan pemuda desa melalui PRA (Participatory Rural Appraisal) desa Gunting Kecamatan Sukorejo Kabupaten Pasuruan, dimana PRA adalah pendekatan dan metode yang memungkinkan masyarakat secara bersama-sama menganalisis masalah kehidupan dalam rangka merumuskan perencanaan dan kebijakan secara nyata.

Adapun proses kegiatan pendampingan ini yang dilakukan tim pendampingan adalah dengan melakukan beberapa tahap yaitu:

a. Tahap Observasi

Dalam Tahap Pra pelaksanaan dilakukan observasi awal di daerah dampingan dengan cara memetakan masalah, sosialisasi kegiatan, penentuan program- program yang berkaitan dengan permasalahan yang ada, dan koordinasi dengan perangkat desa serta warga masyarakat Desa Gunting. Tahap selanjutnya adalah tahap pelaksanaan yang meliputi hal-hal sebagai berikut. (a) Penyelenggaraan FGD dilaksanakan dengan melibatkan warga yaitu ibu- ibu PKK desa Gunting. (b) Pendampingan kepada masyarakat berupa memberikan pelatihan dan keterampilan dalam mengelolah hasil buah Matoa dan buah Pepaya dijadikan olahan produk Manisan, dodol, selai dan minuman . Tahap selanjutnya adalah pascapelaksanaan yang berupa pemonitoran dan evaluasi kegiatan. Pada tahap ini dilaksanakan pemantauan kegiatan beserta hasil-hasilnya.

b. Tahap PRA (Participatory Rural Appraisal)

Rencana pelaksanaan program kegiatan tim pendampingan dilaksanakan dengan pendekatan pemberdayaan masyarakat dan pemuda desa melalui PRA (Participatory Rural Appraisal) Desa Gunting Kecamatan Sukorejo Kabupaten Pasuruan, dimana PRA adalah pendekatan dan metode yang memungkinkan 
66 | Sinergitas Program Matoasisasi pada Masyarakat Desa Gunting...

masyarakat secara bersama-sama menganalisis masalah kehidupan dalam rangka merumuskan perencanaan dan kebijakan secara nyata. Masalah- masalah yang sudah dipetakan dan dirumuskan oleh tim pendampingan dan masyarakat Desa Gunting di rumuskan dan diadakan aksi yang nyata dalam program Matoanisasi.

\section{Hasil dan Diskusi}

Pemilihan program ini dilakukan melalui kegiatan observasi terlebih dahulu untuk mencari permasalahan-permasalahan yang terjadi di lingkungan masyarakat, sekolah, dan lembaga termasuk potensi masyarakat di wilayah Desa Gunting, Tim menginventarisasi permasalahan-permasalahan yang terjadi, sekaligus mengelompokkan atas bidang dan sifatnya. Hasil dari permasalahan yang diinventarisasi dan dikelompokkan tersebut dipilih dan dijadikan sebagai program kerja, dengan mempertimbangkan faktor-faktor yang mendukung pelaksanaan program tersebut dan mencakup kebutuhan masyarakat dan pemerintah setempat, pengetahuan dan keterampilan dari Tim pengabdian, waktu yang tersedia, sarana dan materi, serta potensi alam dan penduduknya.

Dengan melihat potensi bibit Matoa yang ada di Desa Gunting Kecamatan Sukorejo Kabupaten Pasuruan, serta masyarakat yang sebagian besar sudah menanam bibit Matoa yang telah diberikan oleh pemerintah kecamatan dan pemerintah Desa, kurangnya pemahaman tentang jenis buah Matoa dan olahan buah Matoa serta cara pemasarannya menjadikan sosialisasi ini dilaksanakan bersama warga desa, pemuda desa dan anak- anak desa Gunting Kecamatan Sukorejo Kabupaten Pasuruan.

Selain fleksibel dalam hal tempat penanaman, Matoa memiliki tampilan daun yang indah dan cocok dijadikan sebagai tanaman hias. Kata Diano, prototype Matoa saat ini dapat ditemui beberapa tumbuh subur dan berbuah di Desa Glagahsari, Mojotengah, Sukorejo dan Gunting. (Suara Pasuruan) 


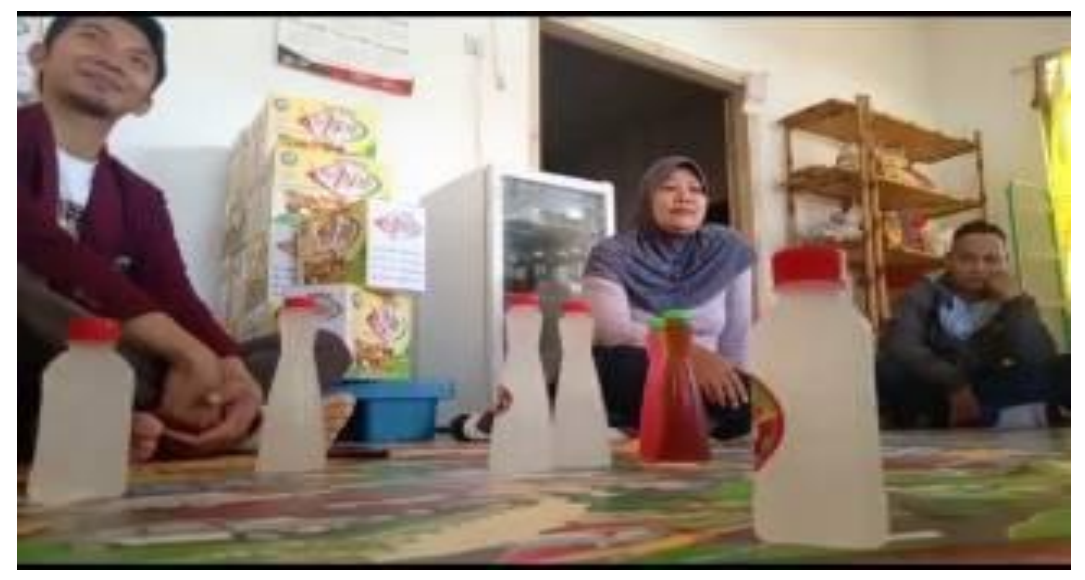

Gambar 1. Sosiliasasi Tentang Matoa

Setelah dilakukannya observasi dan sosialisasi oleh tim, kemudian tim melakukan pengenalan tanaman dan buah Matoa sejak dini, karena sebagian besar masyarakat desa Gunting masih belum mengenal tanaman dan buah Matoa dengan baik. Padahal Matoa merupakan icon dari kecamatan Sukorejo yang tertuang dalam jargon Sukorejo "The City of Matoa".

Menindaklanjuti kegiatan sosialisasi dan pelatihan pengolahan berbahan dasar papaya tersebut, tim mengadakan program pengenalan Matoa sejak dini. Sebagai sasaran program ini adalah ibu- ibu warga desa Gunting, pemuda desa Gunting anak- anak di desa Gunting. Kegiatan ini dengan menghadirkan Ibu Wiji seorang pengusaha pengelolahan buah Matoa.

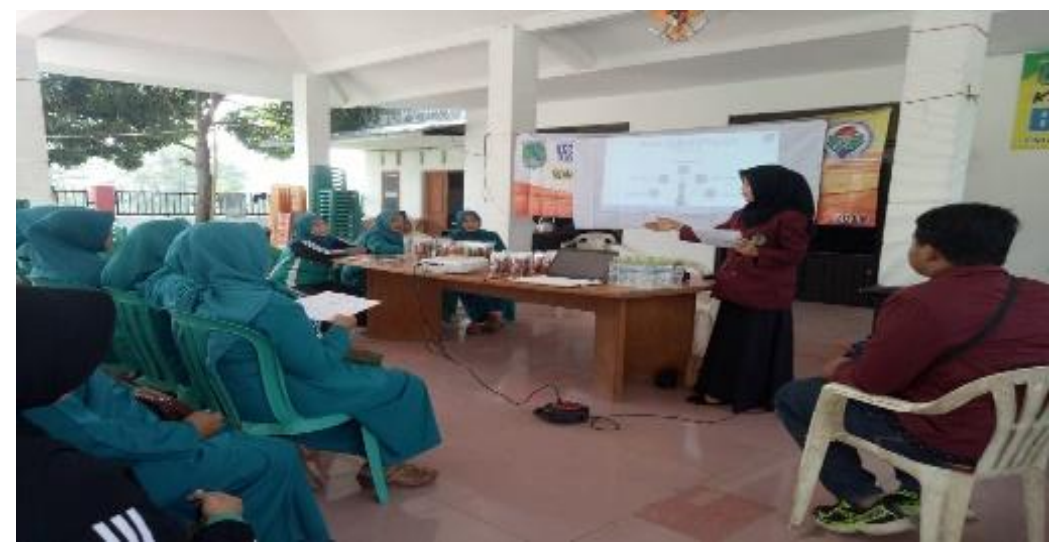

Gambar 2. Sosialisasi dan Pelatihan Matoa 
68 | Sinergitas Program Matoasisasi pada Masyarakat Desa Gunting...

Tim ini memberikan berbagai macam pelayanan bagi masyarakat Desa Gunting kecamatan Sukorejo Kabupaten Pasuruan. Pelayanan-pelayanan tersebut sebagai berikut :

1. Info bisnis dan layanan konsultasi, yaitu apabila masyarakat ingin memahami bisnis tetapi masih belum memahami masalah bisnis, maka tim ini bisa membantu, membimbing, dan mengarahkan.

2. Pendidikan, pelatihan, dan pendampingan, yaitu apabila masyarakat ingin memulai bisnis dan belum memahami sepenuhnya, maka tim dapat mengadakan sosialisasi, pelatihan bahkan pendampingan hingga masyarakat paham apa yang ada dalam dunia bisnis.

3. Perizinan standarisasi, untuk memperluas bisnis, maka yang dibutuhkan adalah perizinan standarisasi seperti PIRT (Produk Industri Rumah Tangga), dengan adanya izin dari PIRT, maka sudah dipastikan bahwa produk yang sudah kita buat sudah layak dan lebih mudah untuk dipasarkan.

4. Pengembangan usaha dan bisnis, dapat dilakukan dengan cara memperluas wilayah pemasaran produk, perluasan wilayah pemasaran produk dapat dilakukan dengan berbagai cara, salah satunya yaitu melakuan media sosial.

\section{Kesimpulan}

Berdasarkan hasil kegiatan pemberdayaan masyarakat desa Gunting kecamatan Sukorejo, maka dapat disimpulkan sebagai berikut:

1. Telah terjadi transfer pengetahuan dan keterampilan seperti pelatihan pembuatan olahan yang berbahan dasar buah Matoa dan buah Pepaya., dimana mayoritas masyarakat sudah memiliki potensi dalam pebudidayaan tanaman- tanaman tersebut. Dengan adanya pelatihan ini bisa membantu memecahkan masalah masyarakat dalam hal pengolahan buah yang berbahan dasar buah Matoa menjadi sari Matoa, dan buah Pepaya untuk menjadi Kripik, Stik, Selai, Dodol dan Manisan Pepaya yang memiliki nilai ekonomi yang tinggi dengan memanfaatkan potensi lokal yang ada di desa Gunting kecamatan Sukorejo. 
2. Tidak hanya pelatihan pengembangan potensi desa dalam menciptakan inovasi produk seperti Kripik, Stik, Selai dan Dodol Pepaya, tetapi juga mereka dibekali dengan rangkaian kegiatan dan pelatihan yang dapat memberikan pemahaman, dan pelatihan tersebut tentang packaging, SNI dan juga pemasaran online untuk lebih menarik minat masyarakat dan terarah dalam berwirausaha.

3. Jaringan kerja terbuka melalui pemanfaatan media sosial yang dapat digunakan sebagai sarana pemasaran. Pelatihan ini bisa membantu warga untuk lebih memperluas penjualan produknya. 
70 | Sinergitas Program Matoasisasi pada Masyarakat Desa Gunting...

\section{Daftar Pustaka}

Abdullah. 2012. Participatory Rural Appraisal (PRA): An Analysis of Experience in Darmareja. Journal of Southeast Asia Social Sciences and Humanities. Vol 82, No 1

Amanatul Zuhriyah, Silvia. 2019. Pola Komunikasi Pemerintah Desa Gunting Kecamatan Sukorejo Kabupaten Pasuruan dalam Melaksanakan Program Matoanisasi. Jurnal HERITAGE Vol 7 No 1.

Arisswan Edy, Mareta, dkk. Pengembangan Booklet Penyuluhan " Nata de Matoa” Bagi Para Petani Buah Matoa. Jurnal Pendidikan UM Vol.2 No.7

Lestari, Desi., Sururi. 2016 .Analisis Program Diklat Participatory Rural Appraisal (Perencanaan Partisipatif). Jurnal Administrasi PendidikanVol 23, No 1

Pasuruan go.id/ berita-4713-kecamatan Sukorejo- The City of Matoa. Html.

Kecamatan Sukorejo. The City of Matoa/ Situs Resmi

Sanusi, Herman., Hidayah, Abdul Kholik. 2015. Pengkajian Potensi Desa Dengan Pendekatan Partisipatif Di Desa Mawai Indah Kecamatan Batu Ampar Kabupaten Kutai Timur. Jurnal AGRIFOR Volume XIV Nomor 2

Supriatna, Asep. 2014. Relevansi Metode Participatory Rural Appraisal Dalam Mendukung Implementasi Undang-Undang Pemerintahan Desa. Jurnal Lingkar Widyaiswara. Vol.1 No.1 